\title{
Chemical Composition, in vitro Cytotoxic, and Antibacterial Activities of Moroccan Medicinal Plants Euphorbia resinifera and Marrubium vulgare
}

\author{
Ahmed Talbaoui ${ }^{1}$, Lahcen El Hamdaoui ${ }^{2}$ (D), Abdelhakim Bouyahya ${ }^{1, *}$ (D), Mohammed El Moussaouiti ${ }^{2}$, \\ Youssef Bakri ${ }^{1}$ (D) \\ 1 Laboratory of Human Pathologies Biology, Department of Biology, Faculty of Sciences, and Genomic Center of Human \\ Pathologies, Mohammed V University, Rabat, Morocco \\ 2 Laboratory of Materials Nanotechnology and Environment, Faculty of Sciences, Mohammed V University, Rabat, \\ Morocco \\ * Correspondence: boyahyaa-90@ hotmail.fr;
}

Scopus Author ID 57190813643

Received: 12.05.2020; Revised: 7.06.2020; Accepted: 8.06.2020; Published: 12.06.2020

\begin{abstract}
The purpose of our study was to bring elements of knowledge on the anticancer and antibacterial effects of two plants, widely used in Moroccan traditional pharmacopeia. These plants are: Marrubium vulgare and Euphorbia resinifera. The aerial parts of each plant were extracted successively with Hexane, Dichloromethane, and finally with methanol. The MTT-based method was applied to evaluate the cytotoxicity of the cancer cells: animal cells BSR and Vero and human cell RD. We evidenced an anticancer activity of the extract of the Marrubium vulgare and the dichloromethane extract of Euphorbia resinifera against the studied cells. The antibacterial activity was evaluated for three species of Rhodococcus: Rhodococcus equi, and strains GK1, GK3, grown in a liquid medium, or this medium solidified with agar. In the last test, the method is based on substance diffusion from well throughout the solid medium. The obtained profiles showed that the growth of bacteria is strongly inhibited by the extracts of Marrubium vulgare. However, the extracts of Euphorbia resinifera had no significant effect on bacterial growth. The chemical analysis of the raw extracts of Marrubium vulgare and Euphorbia resinifera by GC-MS analysis showed the presence of several major chemical compounds, mainly: octadecane, 2,6,10,15-tetramethylheptadecane, 2,6,10-trimethyltetradecane, linoleic acid, and deisopropylatrazine. Our observations an encouraging for deepening the studies of the extracts, in order to target better the active molecules, isolate them and to determine their mechanisms of action. The suggested studies would result in the much better valorization of these two medicinal plants.
\end{abstract}

Keywords: Euphorbia resinifera; Marrubium vulgare; bioactive compounds; antibacterial activity; anticancer activity.

(C) 2020 by the authors. This article is an open-access article distributed under the terms and conditions of the Creative Commons Attribution (CC BY) license (https://creativecommons.org/licenses/by/4.0/).

\section{Introduction}

Cancer is a complex disease that constitutes the second cause of death worldwide after cardiovascular diseases. It continues to present the largest cause of mortality and morbidity in the world. The cancer is caused by deregulation in the genetic and epigenetic programs that affect cell division $[1,2]$. The treatment of cancer is based essentially on chemotherapy using synthetic drugs. This treatment presents many seed effects such minor ones as vomiting, diarrhea, or major ones such as neurological, cardiac, pulmonary, and renal toxicity. On the 
other hand, infectious diseases continue to cause major health problems for developing countries. Indeed, bacteria have developed sophisticated mechanisms that allowed them to resist antibiotics action [3,4]. The resistance of bacteria to antibiotics has today constituted a veritable question in the health system toward infection diseases [5, 6].

Rhodococcus equi infection is commonly encountered in HIV-infected patients; recipients of organ transplants; and in those with lymphoma, chronic renal failure, alcoholism, lung cancer, leukemia, diabetes mellitus, and other states of immunodeficiency. The most common manifestations of Rhodococcus equi infections are multiple abscesses in the lungs, and extra-pulmonary infections may include wound infections, subcutaneous abscesses, brain abscesses, meningitis, pericarditis, osteomyelitis, cervical adenopathy, endophthalmitis, lymphangitis, or mastoiditis [7]. Recently, the search on natural and synthetic molecules with antibacterial and anticancer activities has received much interest over the past few years $[8,9$, 10]. Among the potential sources of new agents, medicinal plants have long been investigated. The secondary metabolites of medicinal plants contain several chemical bioactive compounds that have shown numerous biological activities such as antibacterial, anticancer, antileishmanial, antilithiatic, and antifungal effects [11, 12]. Morocco is one of the developing countries which have an enormous diversity of plants, and yet the majority stays scientifically neglected and undiscovered [13]. In Morocco, the use of traditional medicine is a widespread practice. The ethnobotanical and ethnopharmacological surveys conducted in different areas allowed the compilation of numerous medicinal plants used to treat several complications [14, 15]. Various of these medicinal plants have been investigated for their in vitro and in vivo pharmacological effects such as antimicrobial, antitumor, antiparasitic, antifungal, and antileishmanial properties $[16,17,11,12]$. These plants contain several chemical compounds, such as terpenoids, flavonoids, tannins, and alkaloids.

In the context of the valorization of Moroccan medicinal plants, two medicinal plants have been studied: Euphorbia resinifera and Marrubium vulgare. The choice of these plants was based on their use in Moroccan traditional medicine. The biological properties were based on the fact that to the best of our knowledge, there is no reported study regarding the anticancer and antibacterial activity of Euphorbia resinifera and Marrubium vulgare extracts. Antibacterial assays have been performed on Rhodococcus species, which present a similar morphology and growth characteristics with Mycobacterium tuberculosis (TB). An attempt has been made to discover new anti-TB agents. The extracts were also tested against RD: Embryonal Rhabdomyosarcoma cancerous cell lines, BSR: Kidney adenocarcinoma of hamster and Vero: Monkey kidney cancerous cell lines.

\section{Materials and Methods}

\subsection{Plant material and preparation of extracts.}

Extracts were prepared from Euphorbia resinifera and Marrubium. Table 1 summarizes the taxonomic classification of the plants, vernacular name, different parts of plants collected, traditional use, and pharmacological activities. Each plant was dried in the shade under the normal environmental condition and homogenized to coarse powder before use, the powdered materials were then weighed (300 g) and charged into soxhlet apparatus, and extraction was carried out with following solvents successively: hexane, dichloromethane, and methanol. The filtrate obtained was concentrated in a rotary evaporator to obtain the crude extract. The crude extracts were kept at $4{ }^{\circ} \mathrm{C}$ until further uses. 
Table 1. Ethnobotanical data and some reported pharmacological activities of Euphorbia resinifera and Marrubium vulgare plants.

\begin{tabular}{l|l|l|l|l} 
Plant species & Trivial name & Part plant collected & Traditional use & Pharmacological activities \\
\hline $\begin{array}{l}\text { Euphorbia } \\
\text { resinifera }\end{array}$ & Tîkîut & Aerial parts & Analgesic & $\begin{array}{l}\text { Antioxidant and antibacterial } \\
\text { activity [18] }\end{array}$ \\
\hline $\begin{array}{l}\text { Marrubium } \\
\text { vulgare }\end{array}$ & Merryût & Aerial parts & Liver disorders & $\begin{array}{l}\text { Antioxidant properties [19] } \\
\text { Hepatoprotective activity [20] }\end{array}$
\end{tabular}

2.2. Analytical techniques.

Gas chromatography-mass spectrometry (GC/MS) analysis of the different extracts was performed on a TRACE GC ULTRA Polaris Q (Thermo Electron Corporation) equipped with non-polar VB-5 (5\% phenyl, 95\% methylpolysiloxane) capillary column (30 mm x $0.25 \mathrm{~mm} \mathrm{x}$ $0.25 \mu \mathrm{M}$ film thickness), directly coupled to a mass spectrometer (Polaris Q). The electron ionization energy was set at $70 \mathrm{eV}$ [21]. The oven temperature was programmed from 60 to $280{ }^{\circ} \mathrm{C}$ at $4{ }^{\circ} \mathrm{C} / \mathrm{min}$, then for 280 to $300{ }^{\circ} \mathrm{C}$ at $20^{\circ} \mathrm{C} / \mathrm{min}$. The components of the extracts were identified by comparison of their mass spectra with those in the Willey NIST $7^{\text {th }}$ Edition Library of mass spectra data. The composition of the extracted sample was calculated from GC-MS peak areas and given by percentages.

\subsection{Cell Viability Assays.}

The in vitro cytotoxic effect of the various extracts was evaluated on RD: Embryonal Rhabdomyosarcoma cancerous cell lines (ATCC $\mathrm{N}^{\circ}$ CCL-136), BSR: Kidney adenocarcinoma of hamster (ATCC $\mathrm{N}^{\circ}$ CCL-10), Vero: Monkey kidney cancerous cell lines (ATCC $\mathrm{N}^{\circ} \mathrm{CCL}-$ 81). Cells were grown in Dulbecco's Modified Eagle Medium (DMEM) (GIBCO) supplemented with $10 \%$ heat-inactivated fetal calf serum and $1 \%$ Penicillin-Streptomycin mixture. Cultures were maintained at $37^{\circ} \mathrm{C}$ in $5 \% \mathrm{CO}_{2}$ and $100 \%$ relative humidity atmosphere. The effect of the isolated extracts on cell viability was assessed using the 3-(4,5dimethylthiazol-2-yl)-2,5 diphenyltetrazolium bromide (MTT) assay, which measures the metabolic activity of mitochondria [22]. MTT assays are presently the preferred methods of cytotoxicity assessment in our laboratory [23, 24, 25]. The tests were conducted on 96-well microplate. Before treatment with extracts, $100 \mu \mathrm{L}$ medium DMEM (GIBCO) containing 3 $4 \times 106$ cells $/ \mathrm{mL}$ were placed in each well containing DMEM (GIBCO) and cultured at $37{ }^{\circ} \mathrm{C}$ in $5 \% \mathrm{CO}_{2} /$ humidified air for $24 \mathrm{~h}$. After $24 \mathrm{~h}$ incubation and attachment, cells were treated with crude extracts. Exactly from the stock solution $(80 \mathrm{mg} / \mathrm{mL})$, each extracted sample was applied in a series of 6 dilutions (final concentrations ranging from 12.5 to $400 \mu \mathrm{g} / \mathrm{mL}$ ) in dimethylsulfoxide (DMSO 1\%). Test solution $(100 \mu \mathrm{L})$ was added in decreasing concentrations in duplicate. The microplate was then incubated for $48 \mathrm{~h}$ at $37^{\circ} \mathrm{C}$ in the air condition of $5 \%$ $\mathrm{CO}_{2}$. After, a $20 \mu \mathrm{L}$ MTT solution $(5 \mathrm{mg} / \mathrm{mL}$ ) (SIGMA) was added to the wells containing cells. The cells were incubated for $4-5 \mathrm{~h}$ at $37{ }^{\circ} \mathrm{C}$ in $5 \% \mathrm{CO}_{2}$. Tetrazolium salts are cleaved to formazan dye by the cellular enzyme (only in the viable cells). A solubilization solution (Isopropanol/hydrochloric acid) is added to dissolve the insoluble purple formazan product into a coloration solution. The absorbance was measured at $545 \mathrm{~nm}$, using a microplate reader (Statfax 2100). Tests were carried out in duplicate. Cells were incubated with different concentrations. Data are expressed as means \pm SD of three independent experiments. 


\subsection{Antibacterial Activity.}

2.4.1. Microorganisms and inoculum preparation.

The bacteria studied were three species of $\mathrm{Gram}^{+}$: Rhodococcus equi isolated from Poulain (France), RhodococcusspGK1 isolated from soil polluted with petrol (France), and Rhodococcus sp GK3 obtained from the soil. Each isolate was inoculated into sterile medium mixture: $\left(\mathrm{NH}_{4}\right) 2 \mathrm{SO}_{4}, \mathrm{Na}_{2} \mathrm{HP}_{4}, \mathrm{KH}_{2} \mathrm{PO}_{4}$, Thiamine, $\left(\mathrm{MgSO}_{4}, 7 \mathrm{H}_{2} \mathrm{O}\right),\left(\mathrm{CaCl}_{2}, 2 \mathrm{H}_{2} \mathrm{O}\right),\left(\mathrm{FeSO}_{4}\right.$, $\left.7 \mathrm{H}_{2} \mathrm{O}\right),\left(\mathrm{MnSO}_{4}, 3 \mathrm{H}_{2} \mathrm{O}\right),\left(\mathrm{ZnSO}_{4}, 3 \mathrm{H}_{2} \mathrm{O}\right)$ and agar for solid medium bacteria growth [26].

\subsubsection{Agar well diffusion method.}

Agar well diffusion method is widely used in many microbiology laboratories to evaluate the antimicrobial activity of plants or microbial extracts [27, 28]. In this well-known procedure, the test samples were first dissolved in DMSO (1\%) who thus did not affect the microbial growth. Briefly, the test was performed in sterile Petri plates containing medium agar. $30 \mathrm{~mL}$ of sterilized medium was poured into sterile Petri plates. After solidification, 100 $\mu \mathrm{L}$ of fresh cultures of Rhodococcus $s p$ (one microorganism per Petri dish) were swabbed on the respective plates. Then, $100 \mu \mathrm{L}$ of extracts were placed in wells previously punched over the agar plates using sterile Pasteur pipette, at various concentrations $(6.25,12.5,25$ and 50 $\mu \mathrm{g} / \mathrm{mL}$ ). All Petri plates were then incubated at $30{ }^{\circ} \mathrm{C}$ for $48 \mathrm{~h}$. The diameters of inhibition zones were measured in millimeters. In addition, the antimicrobial activities of two selected plant extracts on Rhodococcus $s p$ were compared with the commercially available antibiotics. The antibiotic discs such as Chloramphenicol and Ampicillin were placed on the surface of the plates. DMSO $1 \%$ was used as a negative control. The plates were incubated at $30{ }^{\circ} \mathrm{C}$ for $48 \mathrm{~h}$, and after incubation, the diameter of the inhibition zones was measured in mm and recorded [29]. Tests were carried out in duplicate. Bacterial Cells were incubated with plant extracts. Data are expressed as means of inhibition zone in $\mathrm{mm} \pm \mathrm{SD}$ of three independent experiments.

\subsubsection{Time-kill dynamic curves.}

Rhodococcus sp were grown overnight at $30^{\circ} \mathrm{C}$ in $25 \mathrm{~mL}$ medium broth. Each extracts $50 \mu \mathrm{g} / \mathrm{mL}$ were prepared in DMSO $(1 \%)$ and placed in viable bacteria and were shaken and incubated at $30{ }^{\circ} \mathrm{C}$. The density of each culture (designed as bacterial growth) was measured by spectrophotometer at a wavelength of $600 \mathrm{~nm}$ after each time point, indicating the bacterial biomass present in the suspension. The suspension of bacteria strains with no extracts was used as control. Tests were carried out in duplicate. Data are expressed as means of bacterial biomass $(\mathrm{g} / \mathrm{L}) \pm \mathrm{SD}$ of three independent experiments.

\section{Results and Discussion}

\subsection{Phytochemical Analysis}

Freshly prepared extracts were subjected to a preliminary phytochemical screening for various constituents by GC-MS analysis. This study has exhibited the presence of phytochemicals considered as active medicinal chemical constituents (Table 2). The result of the phytochemical analysis shows that important medicinal phytochemicals such as flavonoids, terpenoids, alkaloids, and phlorotannins were present in the samples of two selected plant extracts. 
Table 2. Percentage (\%) of the main components of the Euphorbia resinifera and Marrubium vulgare plant extracts

\begin{tabular}{|c|c|c|}
\hline EREH & Main components & $\%$ \\
\hline & Heptacosane & 26.24 \\
\hline & 1,3,4-Trimethyl-3-cyclohexanyl-1-carboxaldehyde & 14.04 \\
\hline & Ethyl linoleate & 13.63 \\
\hline ERDE & 1,3,4-Trimethyl-3-cyclohexanyl-1-carboxaldehyde & 70.27 \\
\hline & Ledane & 13.11 \\
\hline & Cis-Z- $\alpha$-Bisabolene epoxide & 7.08 \\
\hline & 1,4-bis-(2'-cyclopropyl-2'-methylcyclopropyl)-but-2-en-1-one & 5.89 \\
\hline ERME & Methyl arachidonate & 9.92 \\
\hline & Cis-Z- $\alpha$-Bisabolene epoxide & 5.70 \\
\hline & Methyl ester 9,11-(1,1'-bicyclopropyl)-octanoic acid & 4.71 \\
\hline MVHE & 8-Heptyl pentadecane & 26.22 \\
\hline & 2,6,10-Trimethyl-tetradecane & 7.14 \\
\hline & Linoleic acid & 4.82 \\
\hline & Octadecane & 4.59 \\
\hline MVDE & 2-Methylene-5«alpha»-3«beta»-ol & 6.20 \\
\hline & Methyl ester 9,11-(1,1'-bicyclopropyl)-octanoic acid & 6.00 \\
\hline & 9-octadecanol & 5.22 \\
\hline & 1,3,5-Triazine-2,4-diamine-6-chloro-4-n-ethyl & 4.81 \\
\hline MVME & Methyl arachidonate & 7.92 \\
\hline & Methyl ester 9,11-(1,1'-bicyclopropyl)-octanoicacid & 7.36 \\
\hline & 3-Cyclopropyl carbonyl oxy tridecane & 5.02 \\
\hline
\end{tabular}

\subsection{Cytotoxicity Effects.}

The investigation of the cytotoxic potential of six extracts from Euphorbia resinifera and Marrubium vulgare Moroccan plants that are used in traditional medicine for the treatment of various diseases were conducted on three tumor cell lines RD, BSR, and Vero. Cancerous cell lines were exposed to increasing concentrations ranging from 12.5 to $400 \mu \mathrm{g} / \mathrm{mL}$. Assay by the MTT assay, as described above, indicates that the extracts revealed different cytotoxic activities towards the three cancer cell lines investigated. In general, a dose-dependent decrease in the survival of the three cancerous cell lines.

As shown in Figure 1 and Table 3, Hexane extract (HM) and Dichloromethane extract of $M$. vulgare (DM) are present a good inhibiting effect on the RD cell growth with a total inhibiting effect at $400 \mu \mathrm{g} / \mathrm{mL}$. However, the cytotoxic effects of $M$. vulgare Mehtanolic (MM) extract are not significantly varied with increasing concentrations. Whereas, the extracts of $E$. resinifera presents less important inhibiting effects on the cell growth $\mathrm{RD}$, in the particular hexane extract of E. resinifera with IC50 of $50 \mu \mathrm{g} / \mathrm{mL}$.

Table 3. Inhibition concentration ( $\mathrm{IC}_{50}$ in $\mu \mathrm{g} / \mathrm{mL}$ ) values from $M$. vulgare and E. resinifera on $\mathrm{RD}, \mathrm{BSR}$, and Vero as determined by the MTT assay.

\begin{tabular}{|c|c|c|c|c|c|c|}
\hline \multirow[t]{2}{*}{ Cells } & \multicolumn{3}{|l|}{ M. vulgare } & \multicolumn{3}{|l|}{ E. resinifera } \\
\hline & $\mathrm{HM}$ & $\mathrm{DM}$ & MM & $\mathrm{HE}$ & $\mathrm{DE}$ & $\mathrm{ME}$ \\
\hline RD & $23.67 \pm 2.20$ & - & - & $50.7 \pm 4,89$ & - & $67.57 \pm 4.15$ \\
\hline BSR & $128.8 \pm 7.73$ & $26.42 \pm 2.7$ & $97.8 \pm 5$ & - & $77.2 \pm 4.21$ & $200 \pm 8.32$ \\
\hline Vero & $30.12 \pm 3$ & $50 \pm 3.68$ & $145 \pm 8.2$ & $266.43 \pm 10.20$ & $79.2 \pm 4.63$ & - \\
\hline
\end{tabular}

On the other hand, MM and DM extract induced a complete inhibitory effect on BSR cancerous cell lines was at a concentration of $400 \mu \mathrm{g} / \mathrm{mL}$. The concentrations providing $50 \%$ inhibition (IC50) values of the MM and D M extracts $97.8 \mu \mathrm{g} / \mathrm{mL}$ and $26.42 \mu \mathrm{g} / \mathrm{mL}$, respectively (Figure 2 and Table 3). In the case of E. resinifera extracts, DE extract present a significant inhibiting effect with the inhibition values of $\mathrm{IC}_{50} 77.2 \mu \mathrm{g} / \mathrm{mL}$. In addition, ME extract present a moderate cytotoxicity effect ( $\mathrm{IC}_{50} 200 \mu \mathrm{g} / \mathrm{mL}$ ). In contrast, HE extracts present less important effect on the cell growth BSR. For the Vero cancerous cell lines, we noted that the cancerous 
cell line was more resistant to MM (IC50 $145 \mu \mathrm{g} / \mathrm{mL}$ ) and more sensitive to HM and DM with IC $5030.12 \mu \mathrm{g} / \mathrm{mL}$ and $50 \mu \mathrm{g} / \mathrm{mL}$ respectively (Figure 3 and Table 3 ). In the case of E. resinifera extracts, HE and DE present low inhibit effects on the Vero cell lines with IC50 of 266.43 $\mu \mathrm{g} / \mathrm{mL}$ and $79.2 \mu \mathrm{g} / \mathrm{mL}$, respectively.

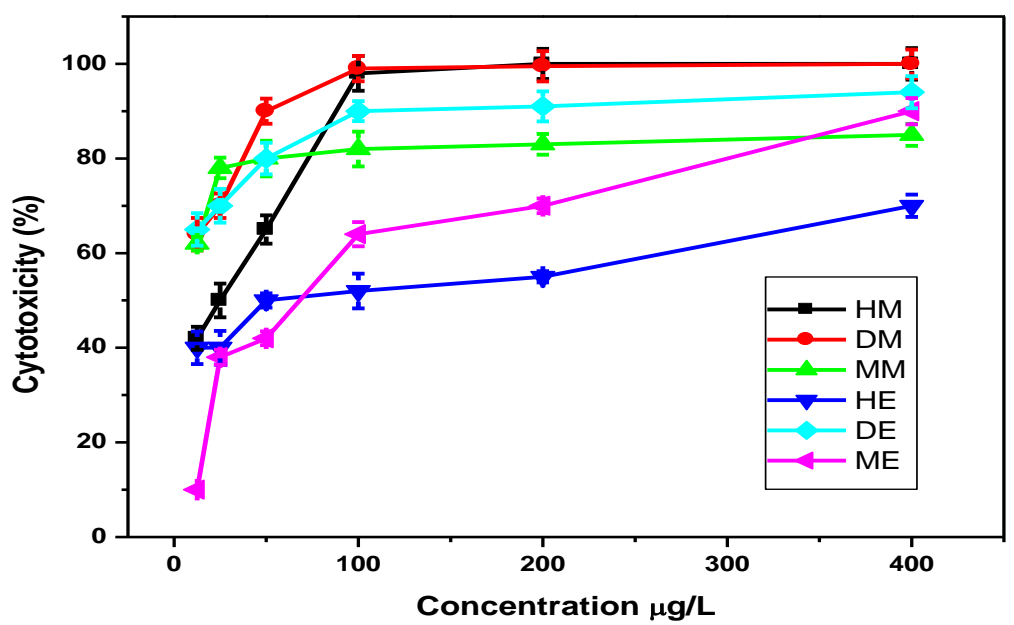

Figure 1. Cytotoxic activity of extracts from 2 medicinal plants against RD cell lines. HM: Hexanic extract from Marrubium vulgare; DM: Dichloromethanic extract from Marrubium vulgare; MM: Methanolic extract from Marrubium vulgare; HE: Hexanic extract from Euphorbia resinifera; DE: Dichloromethanic extract from Euphorbia resinifera; ME: Methanolic extract from Euphorbia resinifera.

\subsection{Antibacterial Activity.}

The results of agar well diffusion and broth dilution methods showed that each extract showed different degrees of growth inhibition. The screening for antibacterial activity indicates that at a concentration of $50 \mu \mathrm{g} / \mathrm{mL}, \mathrm{MM}$ and DM extract was found to possess a relatively high antibacterial activity against $R$. equi with a diameter of inhibition about $32 \mathrm{~mm}$ and 25 $\mathrm{mm}$ respectively (Figure 4 ) and high of growth inhibition (Figure 5). In addition, both DE and HE present a moderate antibacterial activity (Diameter of inhibition about $18 \mathrm{~mm}$ ). Furthermore, each extract from $M$. vulgare was found to be more active at $50 \mu \mathrm{g} / \mathrm{mL}$ concentration against Rhodococcus sp GK1 (inhibition zone ranged from 17 to $25 \mathrm{~mm}$ ) (Figure 6 and Figure 7). In the case of E. resinifera, DE presented a moderate antibacterial activity (Diameter of inhibition about $15 \mathrm{~mm}$ ).

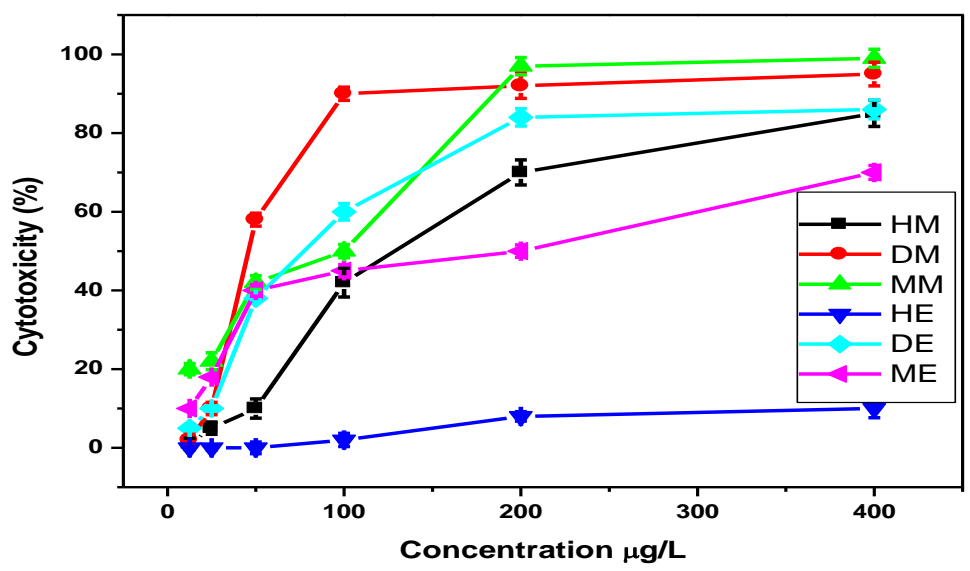

Figure 2. Cytotoxic activity of extracts from 2 medicinal plants against BSR cell lines. HM: Hexanic extract from Marrubium vulgare; DM: Dichloromethanic extract from Marrubium vulgare; MM: Methanolic extract from Marrubium vulgare; HE: Hexanic extract from Euphorbia resinifera; DE: Dichloromethanic extract from Euphorbia resinifera; ME: Methanolic extract from Euphorbia resinifera. 


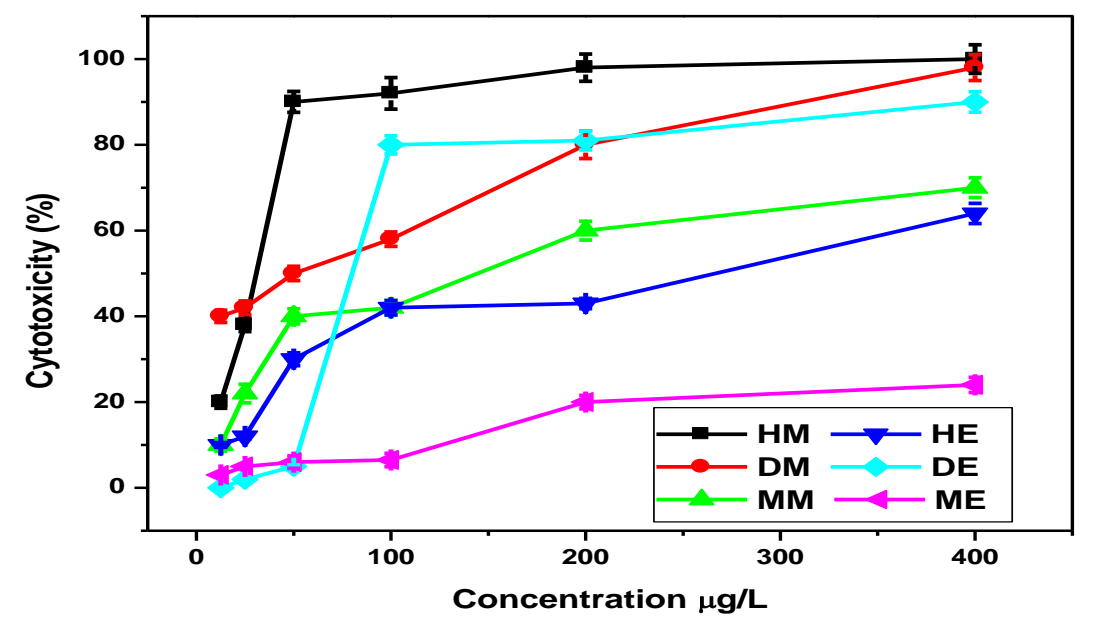

Figure 3. Cytotoxic activity of extracts from 2 medicinal plants against Vero cell lines. HM: Hexanic extract from M. vulgare; DM: Dichloromethanic extract from M. vulgare; MM: Methanolic extract from M. vulgare; HE: Hexanic extract from E. resinifera; DE: Dichloromethanic extract from E. resinifera; ME: Methanolic extract from E. resinifera.

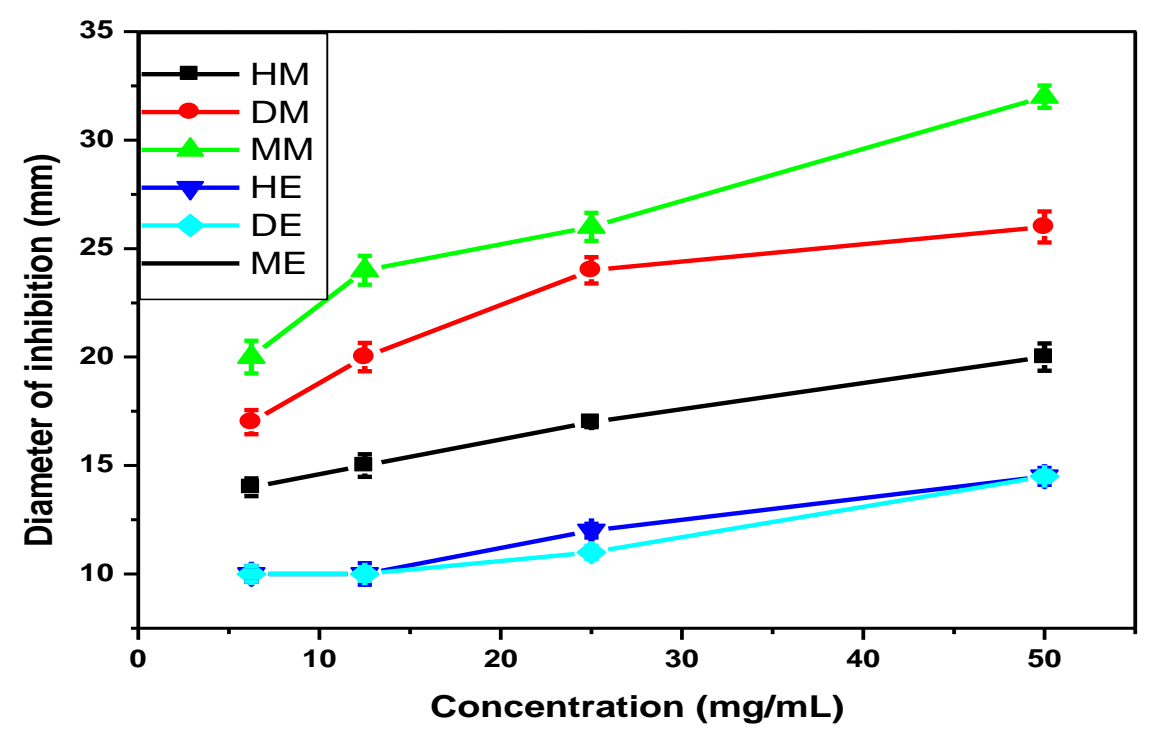

Figure 4. Antibacterial activity of extracts from two Moroccan medicinal plants against Rhodococcus equi as determined by diffusion technique on solid media.

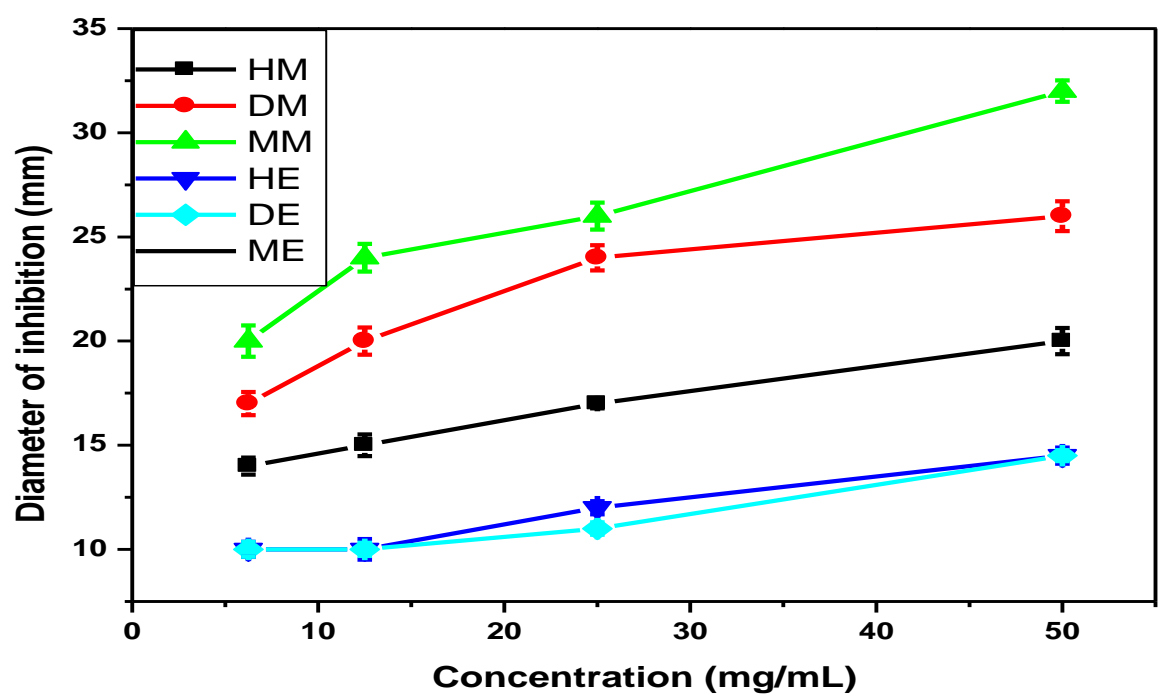

Figure 5. Bacterial growth registered after $40 \mathrm{~h}$ of exposition of each extract on Rhodococcus equi. 


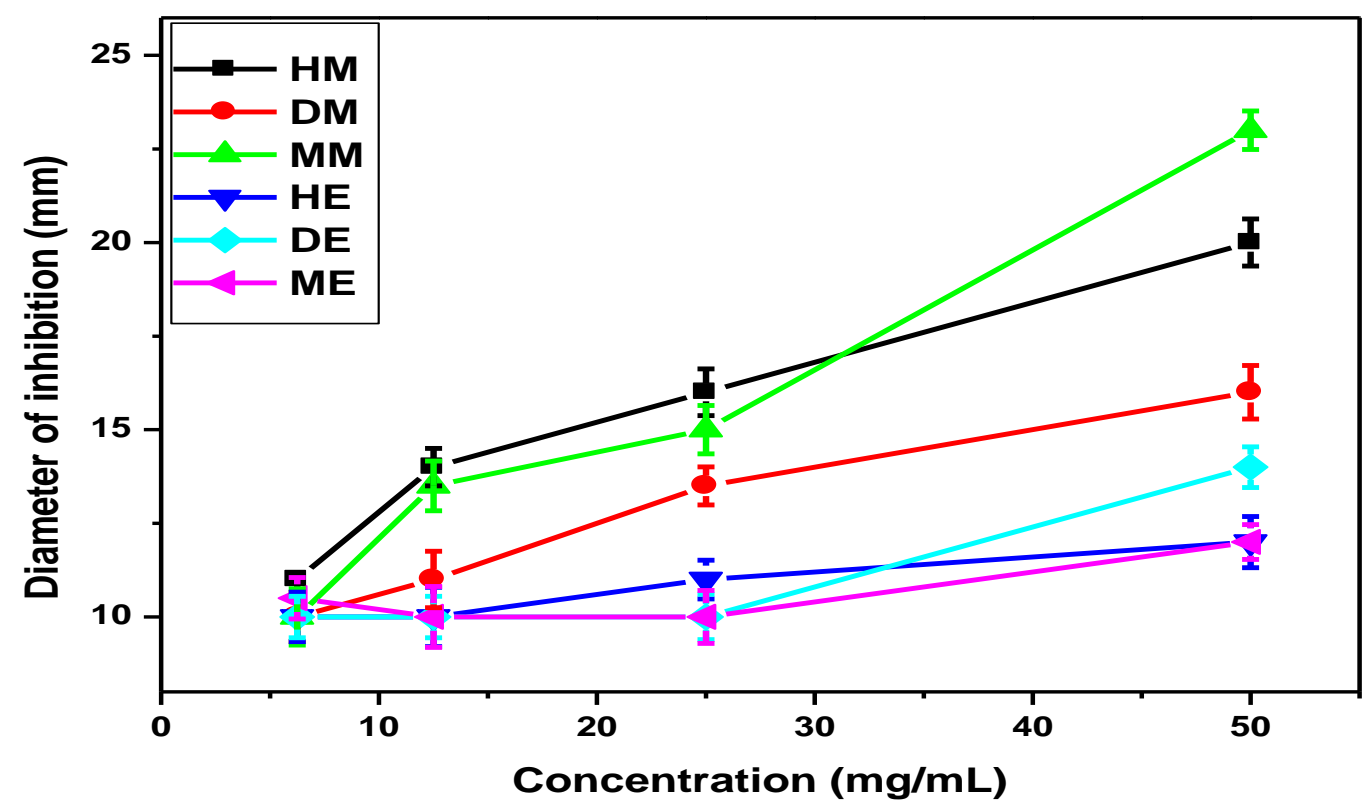

Figure 6. Antibacterial activity of extracts from two Moroccan medicinal plants against Rhodococcus sp GK1 as determined by diffusion technique on solid media.

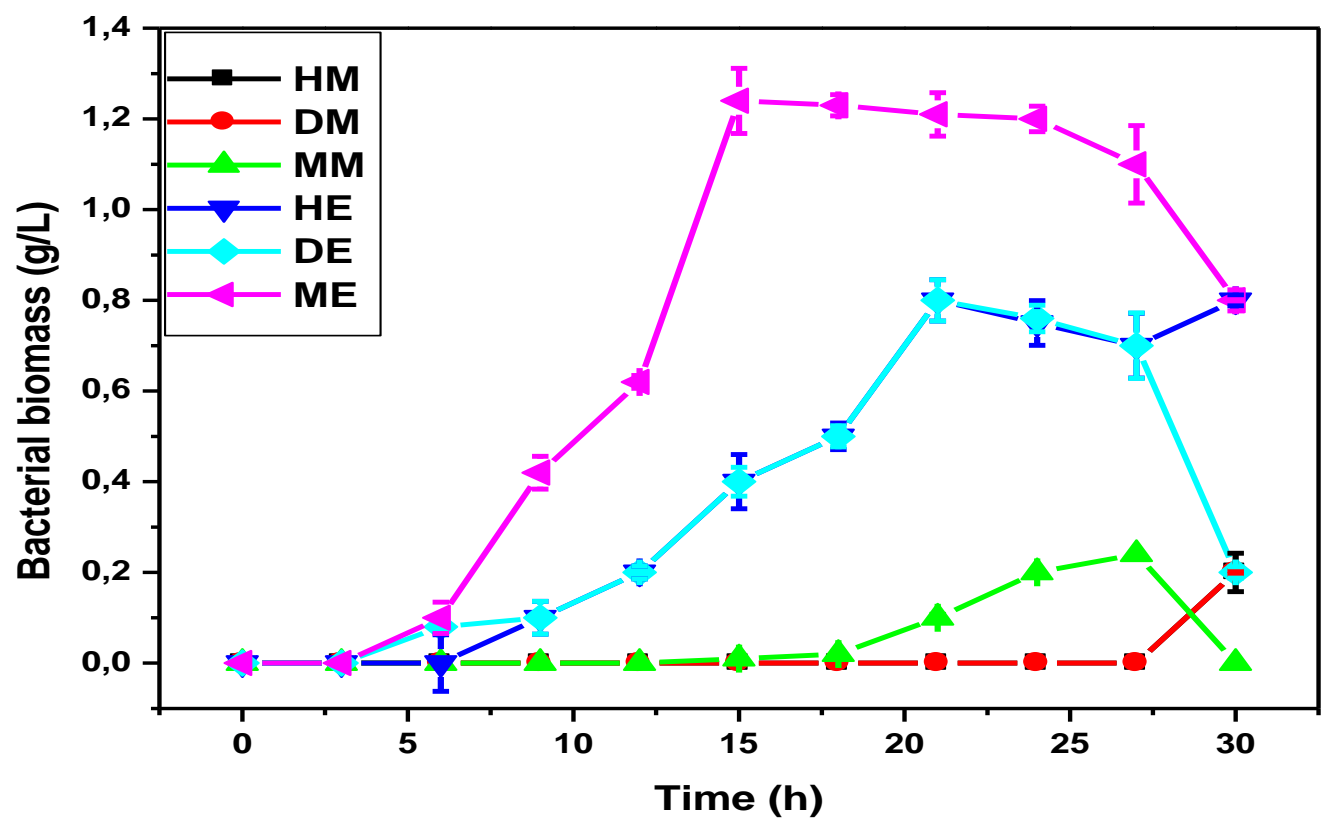

Figure 7. Bacterial growth registered after $30 \mathrm{~h}$ of exposition of each extract on Rhodococcus sp GK1.

As shown in Figure 8 and Figure 9, the Methanolic and Dichloromethanolic extracts of M. vulgare present important inhibiting effects against Rhodococcus sp GK3 (inhibition zone about $35 \mathrm{~mm}$ ). In addition, E. resinifera extracts exhibited low antibacterial activity against Rhodococcus sp GK1 (Diameter of inhibition about $15 \mathrm{~mm}$ at concentration $50 \mu \mathrm{g} / \mathrm{mL}$ ). Chloramphenicol used as reference antibiotics showed important and similar antibacterial activity against all the Rhodococcus population tested with an inhibition zone of $30 \mathrm{~mm}$. So, there was no preferential activity against bacteria strains studied. While the three strains were resistant to ampicillin. In addition, no zone inhibition was observed with DMSO 1\% [21]. 


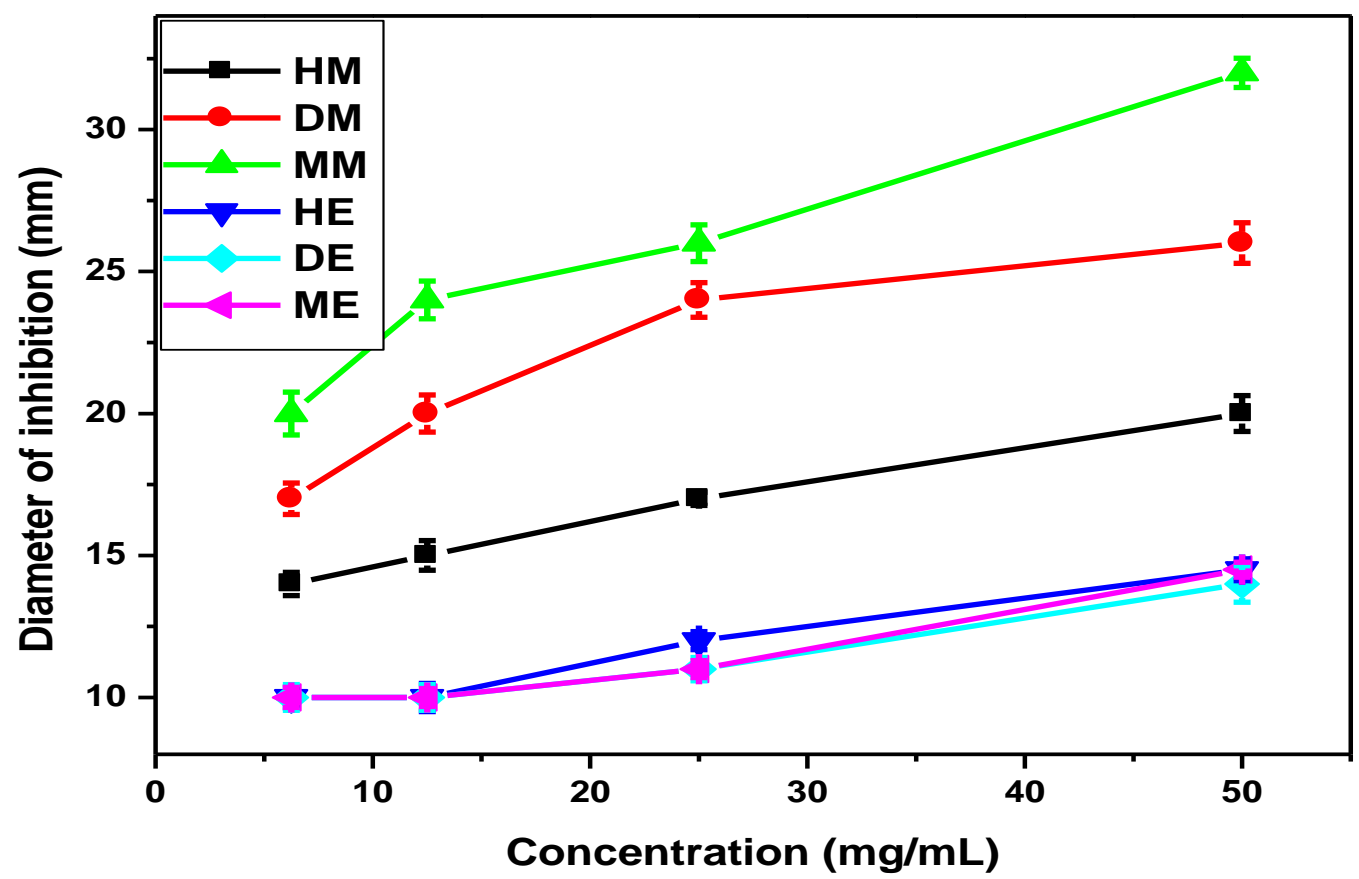

Figure 8. Antibacterial activity of extracts from two Moroccan medicinal plants against Rhodococcus sp GK3 as determined by diffusion technique on solid media.

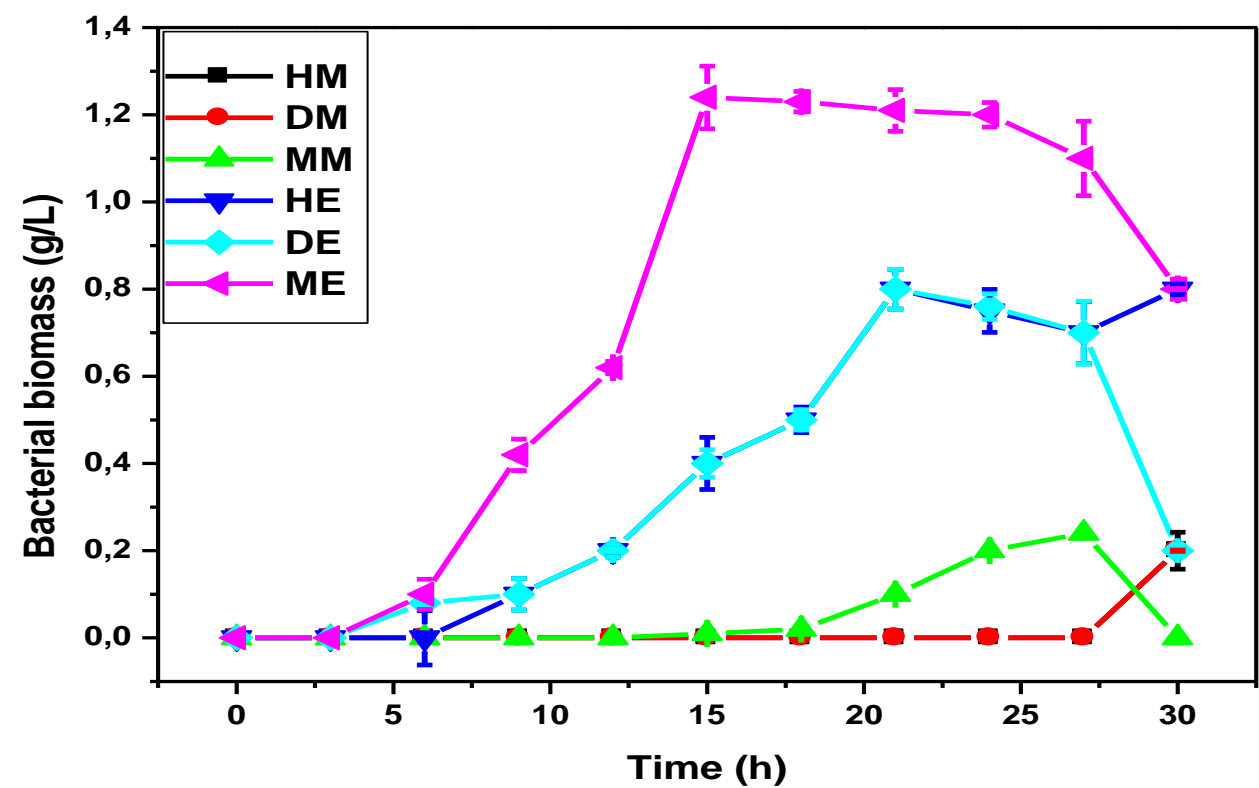

Figure 9. Bacterial growth (measured as bacterial biomass (g/l)) registered after $30 \mathrm{~h}$ of exposition of each extract on Rhodococcus sp GK3.

\subsection{Discussion.}

Medicinal plants have been used to fight against several diseases, including infectious diseases and cancer. These medicinal plants showed several in vitro pharmacological properties such as antibacterial [30], antioxidant [31], anti-lithologic [12], antileishmanial [11] and antitumor activities [32, 33]. Phytochemical compounds of medicinal plants contain a wed variety of bioactive molecules such as essential oils, polyphenols, and flavonoids [9, 8].

In this study, the antibacterial and anticancer activities of Euphorbia resinifera and Marrubium vulgare extracts have been evaluated. Extracts are rich in bioactive compounds that could be involved in biological activities. However, the chemical composition varies between plant species and solvents extraction. Indeed, the synthesis and secretion of secondary 
metabolites depend on genetic factors of each species, geographical location, and methods of extraction [34]. Moreover, the used solvents for extraction have a different polarity, which explains the variation in bioactive chemical compounds between extracts [35, 36]. Bacteria have established resistance against antibiotics. This situation has caused the emergence of infectious diseases [37, 38].

In our study, the antibacterial effect was evaluated against gram ${ }^{+}$species: Rhodococcus equi, Rhodococcus sp GK1, and Rhodococcus sp GK3. Extracts have shown the remarkable antibacterial effect measured by the diameter of inhibition. Moreover, extracts have tested on the kinetic growth of Rhodococcus and showed inhibition of growth at different bacterial time growth. The action of medicinal plant extracts against bacteria has not been well understood. However, some works suggested that secondary metabolites and their derivatives compounds have several mechanisms of action against bacterial [39, 40, 41]. They can target cell membranes (especially against gram ${ }^{+}$bacteria) disturber the respiratory chain of electrons and caused morphological changes in bacteria cells [42, 43]. Moreover, recent studies have shown that bioactive compounds extracted from medicinal plants could deregulate quorum sensing signaling pathways, thus inducing decreasing in cell viability [4].

On the other hand, our extracts are tested against cancer cell lines. We have shown an interesting antiproliferative effect measured by MTT assay. Dichloromethane and Methanol extracts of E. resinifera have demonstrated remarkable anticancer activity against Vero cell lines. Moreover, Methanol extract of M. vulgare was active against BSR cell lines. The anticancer effects of $E$. resinifera and $M$. vulgare have certainly attributed to the main bioactive compounds present in extracts. However, the minor compounds also could participate in these activities by their synergetic effects with the main compounds and/or by their additive effects. The action of natural products on cancer cell lines has been studied by several researches [44, 21]. They may affect the cell division, the apoptosis, the telomerase activity, and angiogenesis [45]. The anticancer activity of our extracts could be attributed to the bioactive chemical compounds such as heptacosane, ethyl linoleate, octadecane and methyl arachidonate.

Other studies have reported the antibacterial effects of E. resinifera [46, 47]. These effects seem to be related essentially to the presence of bioactive compounds such as the phenols [46]. Moreover, M. vulgare extracts have also shown important antibacterial and antiproliferative properties [48, 49]. However, to the best of our knowledge, any study has reported the anticancer properties of E. resinifera extracts.

\section{Conclusions}

This study was investigated by the chemical compounds of E. resinifera and M. vulgare extracts and evaluated their antibacterial and anticancer properties. Dichloromethane and Methanol extracts of E. resinifera showed interested anticancer effects against Vero cell lines, and Hexane extract of $M$. vulgare revealed remarkable activity against BSR cell lines. Moreover, our extracts have shown remarkable antibacterial effects against Rhodococcus species. The findings of our study revealed that E. resinifera and $M$. vulgare extracts are a potential source of antibacterial and anticancer agents. However, further studies regarding the mechanisms of action involved in these effects are needed.

\section{Funding}

This research received no external funding.

https://biointerfaceresearch.com/ 


\section{Acknowledgments}

This research has no acknowledgment.

\section{Conflicts of Interest}

The authors declare no conflict of interest.

\section{References}

1. Bouyahya, A.; Belmehdi, O.; Benjouad, A.; El Hassani, R.A.; Amzazi, S.; Dakka, N.; Bakri, Y. Pharmacological properties and mechanism insights of Moroccan anticancer medicinal plants: What are the next steps? Industrial Crops and Products 2020, 147, https://doi.org/10.1016/j.indcrop.2020.112198.

2. Nasir, A.; Bullo, M.M.H.; Ahmed, Z.; Imtiaz, A.; Yaqoob, E.; Jadoon, M.; Yaqoob, S. Nutrigenomics: Epigenetics and cancer prevention: A comprehensive review. Critical reviews in food science and nutrition 2020, 60, 1375-1387, https://doi.org/10.1080/10408398.2019.1571480.

3. Mc Carlie, S.; Boucher, C.E.; Bragg, R.R. Molecular basis of bacterial disinfectant resistance. Drug Resistance Updates 2020, 48, https://doi.org/10.1016/j.drup.2019.100672.

4. Patini, R.; Mangino, G.; Martellacci, L.; Quaranta, G.; Masucci, L.; Gallenzi, P. The Effect of Different Antibiotic Regimens on Bacterial Resistance: A Systematic Review. Antibiotics 2020, 9, https://dx.doi.org/10.3390\%2Fantibiotics9010022.

5. WHO. World Health Report Health Organisation. Geneva, Switzerland, WHO, Publicat Office, 2003; pp. $1-50$.

6. Yan, W.; Xiao, Y.; Yan, W.; Ding, R.; Wang, S.; Zhao, F. The effect of bioelectrochemical systems on antibiotics removal and antibiotic resistance genes: a review. Chemical Engineering Journal 2019, 358, 1421-1437, https://doi.org/10.1016/j.cej.2018.10.128.

7. Verville, T.D.; Huycke, M.M.; Greenfield, R.A.; Fine, D.P.; Kuhls, T.L.; Slater, L.N. Rhodococcus equi infections of humans: 12 Cases and a Review of the Literature Medicine. Medicine (Baltimore) 1994, 73, 119-132.

8. Kanchi S.; Inamuddin D.; Khan A.; Biogenic Synthesis of Selenium Nanoparticles with Edible Mushroom Extract: Evaluation of Cytotoxicity on Prostate Cancer Cell Lines and Their Antioxidant, and Antibacterial Activity. Biointerface Research in Applied Chemistry. 2020, 10, 6629-6639. https://doi.org/10.33263/BRIAC106.66296639

9. Sahli FZ.; Sassi M.; Labbaci A.; Laredj H.; Antibacterial effect of synthesized silicates for sewage treatment. Biointerface Research in Applied Chemistry. 2018, 8 (2), 3148-3152.

10. Kumar P.; Singh S.; Pratama MRF. Synthesis of some novel 1H-indole derivatives with antibacterial activity and antifungal activity. Letters in Applied NanoBioscience. 2020, 9 (2), 961-967. https://doi.org/10.33263/LIANBS92.961967.

11. Bouyahya, A.; El Omari, N.; Elmenyiy, N.; Guaouguaou, F.E.; Balahbib, A.; El-Shazly, M.; Chamkhi, I. Ethnomedicinal use, phytochemistry, pharmacology, and toxicology of Ajuga iva (L.,) schreb. Journal of Ethnopharmacology, 2020, 158, https://doi.org/10.1016/j.jep.2020.112875.

12. Khouchlaa, A.; El-mehyaoui, A.; Bouyahya, A.; Tijane, M. Determination of phenol content and evaluation of in vitro litholytic effects on urolithiasis of Moroccan Zizyphus lotus L. extract. Phytothérapie 2017, https://doi.org/10.1007/s10298-017-1106-3.

13. Benabid, A. Flore et écosystème du Maroc : évaluation et préservation de la biodiversité. Ibis Press, Paris, 2000; pp. 357.

14. Bouyahya, A.; Abrini, J.; Et-Touys, A.; Bakri, Y.; Dakka, N. Indigenous knowledge of the use of medicinal plants in the North-West of Morocco and their biological activities. European Journal of Integrative Medicine 2017, 13, 9-25, https://doi.org/10.1016/j.eujim.2017.06.004.

15. Eddouks, M.; Maghrani, M.; Lemhadri, A.; Ouahidi, M.L.; Jouad, H. Ethnopharmacological survey of medicinal plants used for the treatment of diabetes mellitus, hypertension and cardiac diseases in the southeast region of Morocco (Tafilalet). Journal of Ethnopharmacology 2002, 82, 97-103, https://doi.org/10.1016/S0378-8741(02)00164-2.

16. Karima, T.; Bentata, F.; Labhilili, M.; Maafa, I.; ELAlaoui-Faris, F.E.; El Aissami, A. Antifungal activity of a Moroccan plant extract against pathogenic fungi Pyrenophorateres, the causal agent of Net Blotch of barle. Journal of Chemical and Pharmaceutical Research 2015, 7, 531-537.

17. Hafsé, M.; Farah, A.; Mouktadir, J.E.; Fikri-Benbrahim, K. Antioxidant and anti-inflammatory activities evaluation of Coriaria myrtifolia from the North of Morocco. International Food Research Journal 2017, 24, 498-502.

18. Farah, H.; Ech-chahad, A.; Lamiri, A. In vitro antioxidant and antibacterial activity of the root extract of Euphorbia resinifera. Journal of Pharmacognosy and Phytochemistry 2014, 2, 161-163.

https://biointerfaceresearch.com/ 
19. Boulila, A. Antioxidant properties and phenolic variation in wild populations of Marrubium vulgare L. (Lamiaceae). Industrial Crops and Products 2015, 76, 616-622, https://doi.org/10.1016/j.indcrop.2015.07.069.

20. Akther, N.; Shawl, A.S.; Sultana, S.; Chandan, B.K.; Akhter, M. Hepatoprotective activity of Marrubium vulgare against paracetamol induced toxicity. Journal of Pharmacy Research 2013, 7, 565-570, https://doi.org/10.1016/j.jopr.2013.06.023.

21. Aneb M.; Bouyahya, A.; Boury, H.E.; Amzazi, S.; Benjouad, A.; Dakka, N.; Bakri, Y. In vitro cytotoxic effects and antibacterial activity of Moroccan medicinal plants Aristolochia longa and Lavandulamultifida. European Journal of Medicinal Plants, 2016, 16, 1-13, https://doi.org/10.9734/EJMP/2016/28534.

22. Mosmann, T. Rapid colorometric assay for cellular growth and survival: Application to proliferation and cytotoxicity assays. Journal of Immunological Methods 1983, 65, 55-63, https://doi.org/10.1016/00221759(83)90303-4.

23. Benjouad, A.; Chapuis, F.; Fenouillet, E.; Gluckman, J.C. Multibranchedpeptid constructs derived from the V3 loop of, envelop glycoprotein gp120 inhibit human immunodeficiency virus type1 infection through interaction with CD4. Virology 1995, 206, 457-64, https://doi.org/10.1016/s0042-6822(95)80061-1.

24. Abdeljebbar, L.H. Antiproliferative effects of withanoids from Withaniaadpressa. Therapy 2009, 64, 121127, https://doi.org/10.2515/therapie/2009015.

25. Merghoub, N.; Benacer, L.; Amzazi, S.; Morjani, H.; El Mzibri, M. Cytotoxic effects of some Moroccan medicinal plant extracts on human cervical cell lines. Journal of Medicinal Plants Research 2009, 3, 10451050.

26. Kreit, J.; Germain, P.; Lefebre, G. Extracellular cholesterol oxidase from Rhodococcus sp. Celles. Journal of Biotechnology 1992, 24, 178-188, https://doi.org/10.1016/0168-1656(92)90121-O.

27. Bassolé, I.H.N.; Juliani, H.R. Essential oils in combination and their antimicrobial properties. Molecules 2012, 17, 3989-4006, https://doi.org/10.3390/molecules17043989.

28. Magaldiet, S. Well diffusion for antifungal susceptibility testing. International Journal of Infectious Diseases 2004, 8, 39-45, https://doi.org/10.1016/j.ijid.2003.03.002.

29. Daniyan, S.Y.; Mahammad, H.B. Evaluation of the antimicrobial activities and phytochemical properties of extracts of Tamaridusindica against some diseases causing bacteria. African Journal of Biotechnology 2008, 7, 2451-2453.

30. Tajbakhsh S. In vitro study of antibacterial activity of the alga Sargassum oligocystum from the Persian Gulf. European review for medical and pharmacological sciences 2011, 15, 293-8.

31. Amoo, S.O.; Van Staden, J. Pharmacological properties and in vitro shoot production of Barleria argillicola - A critically endangered South African species. South African Journal of Botany 2013, 85, 87-93, https://doi.org/10.1016/j.sajb.2013.01.001.

32. Noda, H.; Amano, H.; Arashima, K.; Nisizawa, K. Antitumor activity of marine algae. Hydrobiologia 1990, 204, 577-584, https://doi.org/10.1007/BF00040290.

33. Arzu, B.Y.; Fatma, P.K.; Arzu, U.T. In vitro antibacterial and antitumor activities of some medicinal plant extracts, growing in Turkey. Asian Pacific Journal of Tropical Medicine 2013, 6, 616-624, https://doi.org/10.1016/S1995-7645(13)60106-6.

34. Tawaha, K.; Alali, F.Q.; Gharaibeh, M.; Mohammad, M.; El-Elimat, T. Antioxidant activity and total phenolic content of selected Jordanian plant species. Food Chemistry 2007, 104, 1372-1378, https://doi.org/10.1016/j.foodchem.2007.01.064.

35. Aboukhalid, K.; Lamiri, A.; Agacka-Mołdoch, M.; Doroszewska, T.; Douaik, A.; Bakha, M.; Faiz, C.A. Chemical polymorphism of Origanum compactum grown in all natural habitats in Morocco. Chemistry and Biodiversity 2016, 13, 1126-1139, https://doi.org/10.1002/cbdv.201500511.

36. Belkamel, A.; Bammi, J.; Belkamel, A.; Douira, A. Etude de la composition chimique de lhuile essentielle d'une endémique Ibéro-marocaine: Origanum compactum (Benth.). Journal of Animal and Plant Sciences 2013, 19, 2880-2887.

37. Morse, S.S. Factors in the Emergence of Infectious Diseases. Emerging Infectious Diseases, 1995, 1, 7-15, https://doi.org/10.3201/eid0101.950102.

38. Frieri, M.; Kumar, K.; Boutin, A. Antibiotic resistance. Journal of Infection and Public Health 2017, 10, 369-378.

39. Al Neyadi, S.S.; Salem, A.A.; Ghattas, M.A.; Atatreh, N.; Ibrahim, M.A. Antibacterial activity and mechanism of action of the benzazole acrylonitrile-based compounds: In vitro, spectroscopic, and docking studies. European Journal of Medicinal Chemistry 2017, 136, 270-282, https://doi.org/10.1016/j.ejmech.2017.05.010.

40. Zhang, Y.; Liu, X.; Wang, Y.; Jiang, P.; Quek, S.Y. Antibacterial activity and mechanism of cinnamon essential oil against Escherichia coli and Staphylococcus aureus. Food Control 2016, 59, 282-289, https://doi.org/10.1016/j.foodcont.2015.05.032.

41. Ninga, Y.; Yan, A.; Yang, K.; Wang, Z.; Li, X.; Jia, Y. Antibacterial activity of phenyllactic acid against Listeria monocytogenes and Escherichia coli by dual mechanisms. Food Chemistry 2017, 228, 533-540, https://doi.org/10.1016/j.foodchem.2017.01.112. 
42. Bouhdid, S.; Skali, S.N.; Idaomar, M.; Zhiri, J.; Baudoux, A.; Abrini, J. Antibacterial and antioxidant activities of Origanum compactum essential oil. African Journal of Biotechnology 2008, 7, 1563-1570.

43. Bouhdid, S.; Abrini, J.; Zhiri, A.; Espuny, M.J.; Manresa, A. Investigation of functional and morphological changes in Pseudomonas aeruginosa and Staphylococcus aureuscells induced by Origanum compactum essential oil. Journal of Applied Microbiology 2009, 106, 1558-1568, https://doi.org/10.1111/j.13652672.2008.04124.x.

44. Yueet, Z. Prediction of cancer cell sensitivity to natural products based on genomic and chemical properties. Peer Journal 2015, 3, https://doi.org/10.7717/peerj.1425.

45. Bouyahya, A.; Abrini, J.; Bakri, Y.; Dakka, N. Essential oils as anticancer agents news on mechanisms of action. Phytothérapie 2016, 14, https://doi.org/10.1007/s10298-016-1058-z.

46. Mwine, J.T.; Van Damme, P. Why do Euphorbiaceae tick as medicinal plants; A review of Euphorbiaceae family and its medicinal features. Journal of Medicinal Plants Research 2011, 5, 652-662.

47. Wang, S., Liang, H., Zhao, Y., Wang, G., Yao, H., Kasimu, R., Wang, J. New triterpenoids from the latex of Euphorbia resinifera Berg. Fitoterapia 2016, 108, 33-40, https://doi.org/10.1016/j.fitote.2015.11.009.

48. Zarai, Z.; Kadri, A.; Chobba, I.B.; Mansour, R.B.; Bekir, A.; Mejdoub, H.; Gharsallah, N. The in-vitro evaluation of antibacterial, antifungal and cytotoxic properties of Marrubium vulgare L. essential oil grown in Tunisia. Lipids in health and disease 2011, 10, https://dx.doi.org/10.1186\%2F1476-511X-10-161.

49. Hamedeyazdan, S.; Fathiazad, F.; Sharifi, S.; Nazemiyeh, H. Antiproliferative activity of Marrubium persicum extract in the MCF-7 human breast cancer cell line. Asian Pacific Journal of Cancer Prevention 2012, 13, 5843-5848, https://doi.org/10.7314/apjcp.2012.13.11.5843. 